\title{
The Association Between Major Birth Defects and Preterm Birth
}

\author{
Margaret A. Honein · Russell S. Kirby $\cdot$ Robert E. Meyer $\cdot$ Jian Xing • \\ Nyasha I. Skerrette · Nataliya Yuskiv · Lisa Marengo · Joann R. Petrini · \\ Michael J. Davidoff - Cara T. Mai - Charlotte M. Druschel · Samara Viner-Brown • \\ Lowell E. Sever · for the National Birth Defects Prevention Network
}

Published online: 17 May 2008

(C) Springer Science+Business Media, LLC 2008

\begin{abstract}
Objective To evaluate the association between preterm birth and major birth defects by maternal and infant characteristics and specific types of birth defects. Study Design We pooled data for 1995-2000 from 13 states with population-based birth defects surveillance systems, representing about $30 \%$ of all U.S. births. Analyses were limited to singleton, live births from 24-44 weeks gestational age. Results Overall, birth defects were more than twice as common among preterm births (24-36 weeks) compared with term births (37-41 weeks gestation) (prevalence ratio $[\mathrm{PR}]=2.65,95 \%$ confidence interval $[\mathrm{CI}] 2.62-2.68)$, and approximately $8 \%$ of preterm births had a birth defect. Birth defects were over five times more likely among very preterm births (24-31 weeks gestation) compared with term births $(\mathrm{PR}=5.25,95 \%$ CI $5.15-5.35)$, with about $16 \%$ of very
\end{abstract}

M. A. Honein $(\bowtie) \cdot$ J. Xing $\cdot$ N. Yuskiv $~ C$. T. Mai

Centers for Disease Control and Prevention, Atlanta, 1600

Clifton Rd, NE, Mailstop E-86, GA 30333, USA

e-mail: MHonein@cdc.gov

R. S. Kirby

Department of Maternal and Child Health, School of Public Health, University of Alabama at Birmingham, Birmingham, AL, USA

R. E. Meyer

North Carolina Birth Defects Monitoring Program, Division of Public Health, North Carolina Department of Health and Human Services, Raleigh, NC, USA

\section{N. I. Skerrette}

Rollins School of Public Health, Emory University, Atlanta, GA, USA

L. Marengo

Birth Defects Epidemiology and Surveillance Branch, Texas Department of State Health Services, Austin, TX, USA preterm births having a birth defect. Defects most strongly associated with very preterm birth included central nervous system defects $(\mathrm{PR}=16.23,95 \%$ CI $15.49-17.00)$ and cardiovascular defects $(\mathrm{PR}=9.29,95 \%$ CI 9.03-9.56). Conclusions Birth defects contribute to the occurrence of preterm birth. Research to identify shared causal pathways and risk factors could suggest appropriate interventions to reduce both preterm birth and birth defects.

Keywords Birth defect · Preterm birth · Gestational age

\section{Introduction}

Birth defects and preterm birth are the leading causes of infant death in the United States [1]. Each year approximately $3 \%$ of babies in the United States $(120,000)$ are

\author{
J. R. Petrini · M. J. Davidoff \\ Perinatal Data Center, March of Dimes Foundation, White Plains, \\ NY, USA \\ J. R. Petrini \\ Department of Obstetrics and Gynecology and Women's Health, \\ Albert Einstein College of Medicine, Bronx, NY, USA \\ C. M. Druschel \\ Bureau of Environmental and Occupational Epidemiology, \\ New York State Department of Health, Albany, NY, USA \\ S. Viner-Brown \\ Rhode Island Department of Health, Providence, RI, USA \\ L. E. Sever \\ Battelle Centers for Public Health Research and Evaluation, \\ Seattle, WA, USA \\ for the National Birth Defects Prevention Network
}


born with major birth defects and $12.5 \%$ (nearly half a million) are born preterm (less than 37 completed weeks of gestation) [2, 3]. While separate efforts have monitored the occurrence of birth defects and preterm birth, the role of birth defects in the occurrence of preterm birth is not well understood [4]. A recent hospital-based study in Argentina found an approximate twofold association between birth defects and preterm birth [5].

Existing U.S. regional studies have shown substantial overlap between birth defects and preterm birth. A study in metropolitan Atlanta for the years 1989 through 1995 found that preterm infants were more than twice as likely to have birth defects as term infants (37-41 weeks) (risk ratio $=2.43 ; 95 \%$ confidence interval $[\mathrm{CI}] 2.30-2.56$ ) [2]. Also in metropolitan Atlanta, an inverse relation between birth defects prevalence and birthweights was observed among infants born from 1978 to 1988 [6]. Birth defects prevalence decreased with increasing birthweight from $16.2 \%$ for very low birthweight infants $(<1,500 \mathrm{~g})$ to $3.2 \%$ for normal birthweight (2,500-3,999 g) infants. A study in California of births from 1984 to 1996 found that structural birth defects occurred in more than $8 \%$ of infants born at 30 weeks gestation or less, but only in about $2 \%$ of term infants (37 weeks gestation or greater) [7].

While these studies showed an association between gestational age or birthweight and major birth defects, they represented small geographic areas of the United States and employed differing methodologies. To date, no multistate analyses of birth defects prevalence by gestational age have been conducted. We sought to quantify the proportion of preterm births with major birth defects and evaluate the association between preterm birth and birth defects using combined data from 13 states representing approximately $30 \%$ of all U.S. births from 1995 to 2000 . This large study of a diverse population will help define the combined impact of birth defects and prematurity in the United States.

\section{Methods}

Currently, 35 programs report aggregate data to the National Birth Defects Prevention Network (NBDPN) for inclusion in the NBDPN's annual Congenital Malformations Surveillance Report [8]. We invited all state-based programs reporting data to the NBDPN to participate in this study. To participate, the surveillance system had to provide individual level data on all live-born infants with major birth defects. Participating states included: Colorado, Georgia, Hawaii, Illinois, Kentucky, Michigan, Missouri, New York, North Carolina, Oklahoma, Rhode Island, Texas, and West Virginia. All participating states ascertained major birth defects up to at least 1 year of age. All systems provided statewide data except for Georgia (data from five counties of metropolitan Atlanta only) and Texas (data from various health regions in 1996-1998, statewide for 1999-2000). Ten states provided data for the entire time period of interest (1995-2000). Texas submitted data for 1996-2000 only, while Rhode Island and Kentucky submitted data for 1998-2000. Programs matched their birth defects registry data with state vital statistics and provided selected maternal and infant variables from the birth certificate for infants with a major birth defect. This matched file containing birth defects and birth certificate data served as the numerator for calculations on the prevalence of birth defects among preterm and term births. Denominator data were obtained from U.S. natality files for 1995-2000 (for all participating states except Texas) [9] and from the Texas Vital Statistics Files for Texas to enable the inclusion of only the specific public health regions with birth defects surveillance in 1996-1998. The denominator files were selected to cover the same geographic region and time periods as the available numerator files, and included 7,209,768 live births in the 13 states.

Programs were asked to provide the gestational age for infants with major birth defects using the clinical estimate of gestation as reported on birth certificates. Gestational age for the denominator of total live births was obtained using the same variable from the birth certificates. We excluded infants: (1) less than 24 weeks gestation $(1,625$ [0.55\%] infants with birth defects and 18,179 [0.25\%] total live births) or, (2) greater than 44 weeks $(4,961$ [1.69\%] infants with birth defects and 90,467 [1.25\%] total live births) from all analyses. Infants less than 24 weeks were excluded because: (1) the sensitivity for birth defects ascertainment among births of 20-23 weeks gestation is low, (2) a relatively small proportion of live births compared to other pregnancy outcomes occur at 20-23 weeks gestation, and (3) the bulk of the burden of preterm birth occurs from 24 to 36 weeks gestation. Infants with gestational age greater than 44 weeks were excluded because these represented implausible values of gestational age. All analyses were limited to singleton births because plurality is strongly associated with preterm birth and with many types of major birth defects.

In addition, both the numerator and denominator data were cleaned to exclude implausible gestational age values for a given birthweight [10], meaning those beyond the 1st and 99th percentile distributions of gestational age for birthweight. This cleaning excluded 1,133 (0.42\%) infants with birth defects and $8,326(0.12 \%)$ of the total live births with values of gestational age for a given birthweight that were implausible. Gestational age (in weeks) was categorized as follows: 24-31 (very preterm), 32-36 (moderately preterm), 37-41 (term), and 42-44 (post-term).

Among all births, we excluded conditions that are considered normal conditions of prematurity: patent ductus 
arteriosus, persistent foramen ovale, lung hypoplasia, and undescended testicles. Additionally, because these conditions share the same ICD-9-CM 4-digit codes with other diagnoses, and many systems did not have detail beyond the 4-digit code, we also excluded the following conditions: atrial septal defects (745.5, same code as patent foramen ovale), lung agenesis/aplasia (748.5, same code as lung hypoplasia), and ectopic testis (752.5, same code as undescended testicles). A total of 23,917 infants were excluded from the numerator (infants with birth defects) based on these criteria.

We used the prevalence ratio (PR) to compare the prevalence of birth defects among very preterm births (24-31 weeks) and moderately preterm births (32-36 weeks) with the prevalence of birth defects among term births (37-41 weeks). We calculated 95\% CIs for each PR using SAS PROC GENMOD with the log link model and assuming a Poisson distribution. Stratified analysis was used to assess factors potentially modifying the association between preterm birth and birth defects. Factors assessed included: maternal race/ethnicity (non-Hispanic white, non-Hispanic black, Hispanic, other), maternal age in years (13-24, 25-34, $\geq 35$ ) number of previous live births (none, 1 or more), maternal education ( $<12$ years, 12 years, $>12$ years), initiation of prenatal care (first trimester, second trimester, third trimester, no prenatal care), and delivery method (vaginal, vaginal birth after $\mathrm{C}$-section, primary $\mathrm{C}$-section, repeat $\mathrm{C}$-section). To improve comparability, birth certificates were used as the source of these data for both the numerator and denominator.

The association between birth defects and preterm birth was also analyzed by state of residence and type of defect. We first considered the relation between preterm birth and defects by organ system: central nervous system; eye, face, neck, and ear defects; cardiovascular defects; respiratory defects; orofacial defects; gastrointestinal defects; genitourinary defects; musculoskeletal defects; skin defects; and chromosomal defects. We also assessed selected defects within organ systems. For multivariate analysis, Poisson regression was used to assess the association between preterm births and birth defects while adjusting for state of residence, maternal age, maternal race/ethnicity, and timing of prenatal care [11].

\section{Results}

There were $6,883,582$ singleton live births from 24 to 44 weeks gestation with plausible values of gestational age for birthweight in the 13 states pooled for this analysis (Table 1). Birth defects surveillance systems identified major birth defects in 229,740 of these infants, following exclusions. While nearly eight percent of all singleton, live births in this analysis were delivered preterm (24- 36 weeks gestation by clinical estimate of gestational age), the preterm birth rate among infants with major birth defects was $18.3 \%$. The majority of preterm births occurred between 32 and 36 weeks gestation, both among infants with birth defects (71.9\%) and all live births (85.6\%). Overall, birth defects were more than twice as common among all preterm infants (24-36 weeks gestation) than among term infants (adjusted $\mathrm{PR}=2.65,95 \%$ CI 2.62-2.68), with about $8 \%$ of preterm births having a major birth defect. Birth defects were over five times as likely among very preterm births (24-31 weeks gestation) than among term infants (adjusted $\mathrm{PR}=5.25,95 \%$ CI 5.15-5.35), with about $16 \%$ of very preterm infants having a major birth defect.

Preterm births comprise approximately $6.9 \%$ of nonHispanic white and $7.5 \%$ of Hispanic births, but a much larger percent (11.9\%) of non-Hispanic black births.

Very preterm and moderately preterm birth was more strongly associated with major birth defects among nonHispanic white $(\mathrm{PR}=5.81$ and 2.37 , respectively) and Hispanic mothers ( $\mathrm{PR}=5.71$ and 2.33 , respectively) than among non-Hispanic black mothers ( $\mathrm{PR}=4.45$ and 1.98 , respectively) (Table 2). The association between preterm birth and birth defects was similar across categories of maternal age, maternal education, parity, timing of prenatal care, and delivery method.

Most of the state-specific estimates for the association between both very preterm and moderately preterm birth and birth defects were similar in magnitude to the pooled estimate (Table 3). However, the strongest associations for moderately preterm birth was observed in Illinois (adjusted $\mathrm{PR}=3.61$ ) and the strongest associations for very preterm birth were in Illinois and Hawaii. The weakest associations for moderately preterm birth were in Kentucky (adjusted $\mathrm{PR}=1.69$ ) and Rhode Island (adjusted PR $=1.76$ ).

By organ system, the strongest association between moderately preterm birth and birth defects was for central nervous system defects ( $\mathrm{PR}=4.31,95 \%$ CI 4.15-4.48) (Table 4). Orofacial defects showed a weaker association with preterm birth $(\mathrm{PR}=1.87)$. Musculoskeletal defects as a group were associated with moderately preterm birth ( $P R=2.15$ ), but the subcategory of abdominal wall defects (which includes gastroschisis and omphalocele) was more strongly associated with moderately preterm birth $(\mathrm{PR}=9.24)$. Similarly, while gastrointestinal defects as a group were associated with moderately preterm birth $(\mathrm{PR}=2.81)$, the subcategories for esophageal atresia/tracheoesophageal atresia $(\mathrm{PR}=6.01)$ and small intestinal atresia $(\mathrm{PR}=8.36)$ displayed particularly strong associations. Additional specific birth defects strongly associated with moderately preterm birth included anencephalus $(\mathrm{PR}=9.57)$, congenital hydrocephalus $(\mathrm{PR}=5.44)$, and renal agenesis/dysgenesis $(\mathrm{PR}=5.13)$. 
Table 1 Prevalence of major birth defects by gestational age, 13 states $^{\mathrm{a}}, 1995-2000^{\mathrm{b}}$

\begin{tabular}{|c|c|c|c|c|c|}
\hline $\begin{array}{l}\text { Gestational } \\
\text { age (weeks) }\end{array}$ & $\begin{array}{l}\text { Number of infants } \\
\text { with birth defects }\end{array}$ & $\begin{array}{l}\text { Total live } \\
\text { births }\end{array}$ & $\begin{array}{l}\text { Prevalence } \\
\text { per } 1,000 \text { births }\end{array}$ & $\begin{array}{l}\text { Unadjusted prevalence ratio } \\
\text { ( } 95 \% \text { confidence interval) }\end{array}$ & $\begin{array}{l}\text { Adjusted }^{\mathrm{c}} \text { prevalence ratio } \\
\text { (95\% confidence interval) }\end{array}$ \\
\hline $24-31$ & 11,804 & 76,143 & 155.02 & $5.24(5.15-5.34)$ & $5.25(5.15-5.35)$ \\
\hline $32-36$ & 30,225 & 453,859 & 66.60 & $2.25(2.23-2.28)$ & $2.23(2.21-2.26)$ \\
\hline 24-36 (all preterm) & 42,029 & 530,002 & 79.30 & $2.68(2.65-2.71)$ & $2.65(2.62-2.68)$ \\
\hline $37-41$ & 184,053 & $6,226,677$ & 29.56 & Referent & Referent \\
\hline $42-44$ & 3,658 & 126,903 & 28.83 & $0.98(0.94-1.01)$ & $0.97(0.94-1.01)$ \\
\hline
\end{tabular}

${ }^{a}$ Combined data from: Colorado, Georgia, Hawaii, Illinois, Kentucky, Michigan, Missouri, New York, North Carolina, Oklahoma, Rhode Island, Texas, and West Virginia

b All states included data for 1995-2000 except Kentucky and Rhode Island data (1998-2000), Texas data (1996-2000)

c Adjusted for state, maternal age, maternal race/ethnicity, and timing of prenatal care

\section{Discussion}

This study captured a large, diverse population that comprised over one-quarter of the births in the United States from 1995 to 2000 and had essentially the same maternal age and race/ethnicity distribution as the total U.S. births for that time period [12]. The programs ascertained population-based birth defects data using multiple ascertainment sources. This analysis allowed us to better examine the association between major birth defects and preterm births in a multi-state and geographically and racial/ethnically diverse population.

Overall, infants born preterm were more than twice as likely to have major birth defects as infants born at term, and the association was much stronger at the earliest gestational ages. Very preterm infants (24-31 weeks) had an overall prevalence of birth defects 2.3 times that of moderately preterm infants (32-36 weeks). This gradient might have occurred because some factors such as maternal smoking and diabetes that increase the risk of very preterm birth are also related to the risk of certain birth defects $[13,14]$. The ascertainment of birth defects also depends on the thoroughness and training of the examiner [15]. Very preterm infants might receive a more thorough examination, and defects might be discovered that might not have been diagnosed in a moderately preterm or term infant [15]. Also, preterm infants are often hospitalized longer than term infants, allowing more opportunity for hospital records to include the diagnosis of defects that would not require rehospitalization.

Our findings were similar to those reported for earlier time periods in two regional studies in the United States [2, 7]. Both U.S. studies documented increasing prevalence of birth defects with earlier gestational ages; however, slight differences in study methods and manner of presentation rendered direct comparisons difficult. Shaw et al. included both live births and fetal deaths, but our study was limited to birth defects among live births only because many of the participating states did not conduct comprehensive birth defects surveillance among fetal deaths. We also limited our study to singleton births, as did Rasmussen et al., whereas Shaw et al. included both singletons and multiples. All three studies excluded cases of birth defects related to normal fetal development of preterm births. Both earlier studies also examined the prevalence of each type of birth defect by gestational age limiting analyses to isolated cases with no other major defects, but our analyses combined infants with isolated and multiple major defects. Our findings are also similar to a recent study that compared preterm delivery among those with and without a chromosomal abnormality or major structural birth defects noted at birth, though they reported a stronger association than our data showed for the earliest gestational ages (less than 32 weeks) [16]. And, the findings are also similar to a recent study of preterm birth and cardiovascular defects in England [17].

The causes of most birth defects and the mechanisms or reasons why these birth defects might contribute to preterm birth remain unknown. While it is likely that the most common of these defects result from the interaction of genetic and environmental risk factors, the identification of specific modifiable risk factors continues to be an important research and public health priority. At least two possible pathways could explain the association between preterm birth and birth defects. In some instances, similar or shared risk factors (e.g., maternal smoking, obesity) could act independently to cause both birth defects and preterm birth in an infant. In other cases, a particular risk factor (e.g., valproic acid, insufficient periconceptional folic acid) could lead to a birth defect (e.g., spina bifida), and the presence of that birth defect could then be part of the causal mechanism resulting in a preterm delivery. Certain birth defects are also strongly associated with intrauterine growth restriction [18].

It is well established that folic acid taken prior to conception and early in gestation reduces a woman's risk of having a baby with a neural tube defect (NTD) [19-23] and possibly other defects [24, 25], and recent studies suggest that maternal folate status has a direct effect on low birth 
Table 2 Maternal characteristics for infants with major birth defects by gestational age (very preterm and moderately preterm vs. term), and the prevalence ratio comparing the contribution of birth defects to very preterm and moderately preterm births compared to the contribution of birth defects to term births, 13 states, ${ }^{\mathrm{a}} 1995-2000^{\mathrm{b}}$

\begin{tabular}{|c|c|c|c|c|c|c|c|}
\hline \multirow[t]{2}{*}{ Characteristics } & \multicolumn{3}{|c|}{$\begin{array}{l}\text { Prevalence of birth defects among infants (per } 100 \text { live } \\
\text { births) }\end{array}$} & \multicolumn{4}{|c|}{$\begin{array}{l}\text { Prevalence and unadjusted prevalence ratio (95\% confi- } \\
\text { dence interval) }\end{array}$} \\
\hline & Very preterm $^{\mathrm{c}}$ & Moderately preterm $^{\mathrm{d}}$ & Term $^{\text {e }}$ & Very & $\mathrm{rm}^{\mathrm{c}}$ & Mod & preterm $^{\mathrm{d}}$ \\
\hline \multicolumn{8}{|l|}{ Maternal race } \\
\hline Non-Hispanic White & 14.17 & 5.79 & 2.44 & 5.81 & $5.54-6.09$ & 2.37 & $2.30-2.45$ \\
\hline Non-Hispanic Black & 12.97 & 5.78 & 2.91 & 4.45 & $4.30-4.61$ & 1.98 & $1.93-2.04$ \\
\hline Hispanic & 18.70 & 7.63 & 3.28 & 5.71 & $5.56-5.86$ & 2.33 & $2.29-2.37$ \\
\hline \multicolumn{8}{|l|}{ Mother's age } \\
\hline $13-24$ years & 15.35 & 6.43 & 2.94 & 5.23 & $5.08-5.38$ & 2.19 & $2.15-2.23$ \\
\hline $25-34$ years & 15.35 & 6.56 & 2.89 & 5.32 & $5.17-5.57$ & 2.27 & $2.23-2.31$ \\
\hline$\geq 35$ years & 16.38 & 7.64 & 3.29 & 4.98 & $4.75-5.23$ & 2.32 & $2.25-2.40$ \\
\hline \multicolumn{8}{|l|}{ Maternal education } \\
\hline$<12$ years & 15.02 & 6.34 & 2.93 & 5.13 & $4.95-5.32$ & 2.17 & $2.12-2.22$ \\
\hline 12 years & 15.67 & 6.87 & 3.00 & 5.22 & $5.06-5.39$ & 2.29 & $2.24-2.34$ \\
\hline$>12$ years & 16.57 & 6.90 & 3.00 & 5.52 & $5.36-5.69$ & 2.30 & $2.25-2.34$ \\
\hline \multicolumn{8}{|l|}{ Previous live births } \\
\hline None & 92.09 & 37.12 & 17.31 & 5.32 & $5.17-5.47$ & 2.14 & $2.10-2.18$ \\
\hline Yes ( 1 or more) & 8.82 & 3.97 & 1.81 & 4.88 & $4.75-5.00$ & 2.20 & $2.16-2.23$ \\
\hline \multicolumn{8}{|c|}{ Trimester prenatal care began } \\
\hline 1st trimester & 15.38 & 6.62 & 2.90 & 5.30 & $5.19-5.42$ & 2.28 & $2.25-2.31$ \\
\hline 2nd trimester & 16.53 & 6.82 & 3.13 & 5.28 & $5.02-5.55$ & 2.18 & $2.11-2.25$ \\
\hline 3rd trimester & 10.40 & 6.19 & 3.21 & 3.24 & $2.66-3.94$ & 1.93 & $1.79-2.07$ \\
\hline No prenatal care & 15.62 & 6.95 & 3.26 & 4.79 & $4.55-5.04$ & 2.13 & $2.04-2.22$ \\
\hline \multicolumn{8}{|l|}{ Method of delivery } \\
\hline Vaginal & 13.62 & 5.30 & 2.53 & 5.39 & $5.24-5.54$ & 2.10 & $2.06-2.13$ \\
\hline $\operatorname{VBAC}^{\mathrm{f}}$ & 14.97 & 5.46 & 2.55 & 5.87 & $5.15-6.69$ & 2.14 & $1.97-2.33$ \\
\hline Primary C-section & 16.52 & 9.83 & 4.28 & 3.86 & $3.75-3.98$ & 2.30 & $2.24-2.36$ \\
\hline Repeat C-section & 15.49 & 7.49 & 3.38 & 4.58 & $4.31-4.88$ & 2.22 & $2.13-2.31$ \\
\hline
\end{tabular}

${ }^{a}$ Combined data from: Colorado, Georgia, Hawaii, Illinois, Kentucky, Michigan, Missouri, New York, North Carolina, Oklahoma, Rhode Island, Texas, and West Virginia

b All states included data for 1995-2000 except Kentucky, Rhode Island (1998-2000), and Texas (1996-2000)

c Very Preterm is defined as births of 24 through 31 weeks gestation

d Moderately Preterm is defined as births of 32 through 36 weeks gestation

e Term is defined as births of 37 through 41 weeks gestation

${ }^{\mathrm{f}}$ Vaginal birth after C-section

weight and preterm delivery [26, 27]. Smoking during pregnancy is an independent risk factor for preterm birth and for certain types of birth defects including orofacial clefts and clubfoot [28, 29]. Maternal obesity before pregnancy is a risk factor for NTDs and other types of central nervous system defects, and a possible relation has also been suggested for heart defects, omphalocele, hydrocephalus, and multiple major birth defects [30-32], and maternal obesity is also associated with preterm birth [33]. While the interpretation is unclear given that most of the defects examined in this analysis were associated with preterm birth, modifying certain risk factors might reduce both preterm births and major birth defects.
The array of medical problems faced by infants born with serious birth defects is often compounded by preterm delivery. Depending on the type and severity of the defect(s) present and gestational age at birth, these infants might be at substantially higher risk for major medical complications or mortality compared with their counterparts delivered at term. In an analysis of U.S. linked livebirth/infant-death files for 1996-1998, the relative risk for infant death among preterm infants with NTDs was more than 10 times that of NTD-affected infants born at term [34]. Neonatal mortality among infants born with congenital diaphragmatic hernia was also significantly higher among preterm versus term deliveries [35]. Studies of 
Table 3 State-specific prevalence of birth defects by gestational age and prevalence ratios for birth defects among preterm births compared to term births, 1995-2000

\begin{tabular}{|c|c|c|c|c|c|c|c|}
\hline \multirow[t]{2}{*}{ State } & \multicolumn{3}{|c|}{ Prevalence of birth defects among infants } & \multicolumn{2}{|c|}{$\begin{array}{l}\text { Unadjusted prevalence ratio }{ }^{\mathrm{e}} \text { (95\% con- } \\
\text { fidence interval) }\end{array}$} & \multicolumn{2}{|c|}{$\begin{array}{l}\text { Adjusted prevalence } \text { ratio }^{\mathrm{f}} \text { (95\% confi- } \\
\text { dence interval) }\end{array}$} \\
\hline & $\begin{array}{l}\text { Very } \\
\text { preterm }^{\mathrm{b}}\end{array}$ & $\begin{array}{l}\text { Moderately } \\
\text { preterm }^{c}\end{array}$ & Term $^{\mathrm{d}}$ & Very preterm & $\begin{array}{l}\text { Moderately } \\
\text { preterm }\end{array}$ & Very preterm & $\begin{array}{l}\text { Moderately } \\
\text { preterm }\end{array}$ \\
\hline Colorado & 22.93 & 8.73 & 3.69 & $6.22(5.76-6.71)$ & $2.37(2.25-2.48)$ & $6.21(5.75-6.70)$ & $2.36(2.24-2.48)$ \\
\hline Georgia & 11.22 & 5.90 & 2.51 & $4.47(4.04-4.94)$ & $2.35(2.20-2.51)$ & $5.01(4.52-5.55)$ & $2.45(2.29-2.62)$ \\
\hline Hawaii & 30.19 & 8.02 & 3.06 & $9.86(8.63-11.25)$ & $2.62(2.39-2.87)$ & $9.05(7.89-10.38)$ & $2.52(2.30-2.77)$ \\
\hline Illinois & 13.06 & 4.38 & 1.23 & $10.64(10.09-11.22)$ & $3.57(2.36-2.56)$ & $11.03(10.45-11.65)$ & $3.61(3.47-3.76)$ \\
\hline Kentucky & 16.95 & 9.04 & 5.16 & $3.29(3.43-3.72)$ & $1.75(1.64-1.87)$ & $2.93(2.60-3.30)$ & $1.69(1.59-1.80)$ \\
\hline Michigan & 18.05 & 8.10 & 4.37 & $4.13(3.92-4.34)$ & $1.85(1.79-1.91)$ & $4.06(3.85-4.28)$ & $1.84(1.78-1.90)$ \\
\hline Missouri & 26.05 & 9.66 & 4.29 & $6.07(5.71-6.44)$ & $2.25(2.16-2.34)$ & $6.02(5.66-6.40)$ & $2.24(2.15-2.33)$ \\
\hline New York & 12.73 & 6.14 & 2.83 & $4.49(4.30-4.69)$ & $2.16(2.10-2.23)$ & $4.54(4.34-4.74)$ & $2.16(2.10-2.22)$ \\
\hline $\begin{array}{l}\text { North } \\
\quad \text { Carolina }\end{array}$ & 15.83 & 7.20 & 3.47 & $4.56(4.32-4.82)$ & $2.08(2.00-2.15)$ & $4.56(4.32-4.81)$ & $2.07(2.00-2.15)$ \\
\hline Oklahoma & 10.51 & 6.22 & 2.92 & $3.60(3.18-4.07)$ & $2.13(2.00-2.27)$ & $3.35(2.95-3.80)$ & $2.08(1.95-2.22)$ \\
\hline Rhode Island & 17.92 & 8.48 & 4.60 & $3.89(2.99-5.08)$ & $1.84(1.56-2.17)$ & $3.39(2.59-4.44)$ & $1.76(1.49-2.08)$ \\
\hline Texas & 15.29 & 6.19 & 2.59 & $5.91(5.64-6.19)$ & $2.40(2.33-2.47)$ & $5.95(5.67-6.23)$ & $2.40(2.33-2.47)$ \\
\hline West Virginia & 13.34 & 6.22 & 2.54 & $5.24(4.51-6.09)$ & $2.44(2.23-2.68)$ & $5.27(4.48-6.07)$ & $2.43(2.21-2.66)$ \\
\hline
\end{tabular}

${ }^{a}$ All states included data for 1995-2000 except Kentucky, Rhode Island (1998-2000), and Texas (1996-2000)

b Very Preterm is defined as births of 24 through 31 weeks gestation

c Moderately Preterm is defined as births of 32 through 36 weeks gestation

d Term is defined as births of 37 through 41 weeks gestation

e Unadjusted prevalence ratio and 95\% Confidence Interval calculated using SAS PROC GENMOD

${ }^{\mathrm{f}}$ Adjusted for maternal age, maternal race/ethnicity, and timing of prenatal care, adjusted prevalence ratio and $95 \%$ Confidence Interval calculated with Poisson regression using SAS PROC GENMOD

preterm infants with congenital heart disease showed a similar pattern of increased mortality, and preterm infants with ventricular septal defects (VSDs) were more likely to require surgical repair of the defect compared with term infants with VSDs [17]. Higher operative mortality rates were also reported for preterm infants undergoing open surgical procedures for congenital heart defects compared with term infants [36]. Bronchopulmonary dysplasia (BPD) occurs almost exclusively in very preterm infants, and infants with BPD who underwent surgery for congenital heart disease had significantly higher rates of postoperative complications and mortality compared with age and lesionmatched controls [37].

With continual innovations in high-risk obstetrical and neonatal care and the concomitant improving survival of very preterm infants, the number of infants with major congenital malformations who also experience the serious complications associated with prematurity will likely increase in the future. Some fetuses with certain birth defects have been scheduled for elective early delivery because of possible benefits. For example, early delivery of infants with gastroschisis might be associated with reduced morbidity, improved surgical outcomes, and reduced hospital length of stay; however, to date, the results are mixed
[38-40]. Somewhat stronger associations between preterm birth and birth defects were noted for births delivered by Csection as compared to vaginal delivery, and this could be due in part to scheduled C-sections for pregnancies known to be affected by a defect. Also, for some infants with lethal congenital anomalies, medical interventions to delay preterm delivery are unlikely to be utilized.

There were some limitations to this study. First, only the clinical estimates of gestational age were available for the infants with birth defects; therefore, we were not able to compare the gestational age calculated from the last menstrual period (LMP) with the clinical estimate. Ultrasound has replaced gestational age calculations based on reported LMP as the most commonly used method for gestational age estimation, and this might have increased the number of infants classified as preterm [41-43]. Our gestational age cut points might have excluded some relevant cases from the analysis. Advances in medical technology have increased survival rates among infants born at early gestational ages, with increasing numbers of live births from 20 to 27 weeks gestational age being registered as live births [44]. Conversely, technological improvements also enable earlier prenatal diagnosis of birth defects, potentially resulting in elective terminations of affected fetuses 
Table 4 Association between major birth defects and preterm birth by specific categories of birth defects among live births in 13 states ${ }^{\mathrm{a}}$, $1995-2000^{\mathrm{b}}$

\begin{tabular}{|c|c|c|c|c|c|}
\hline 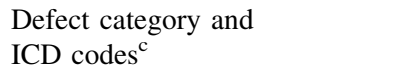 & $\begin{array}{l}\text { Gestational } \\
\text { age (weeks) }\end{array}$ & $\begin{array}{l}\text { Number of infants } \\
\text { with birth defects }\end{array}$ & $\begin{array}{l}\text { Prevalence (per } \\
1,000 \text { live births) }\end{array}$ & $\begin{array}{l}\text { Unadjusted } \\
\text { prevalence ratio }^{\mathrm{d}}\end{array}$ & $\begin{array}{l}95 \% \\
\mathrm{CI}^{\mathrm{d}}\end{array}$ \\
\hline \multirow{3}{*}{$\begin{array}{l}\text { Central nervous system defects } \\
\quad(740.000-742.999)\end{array}$} & 24-31 (very preterm) & 2,127 & 27.93 & 16.23 & $15.49-17.00$ \\
\hline & 32-36 (moderately preterm) & 3,368 & 7.42 & 4.31 & $4.15-4.48$ \\
\hline & $37-41$ (term) & 10,720 & 1.72 & Referent & \\
\hline \multirow{3}{*}{$\begin{array}{l}\text { Anencephalus } \\
\quad(740.000-740.299)\end{array}$} & 24-31 (very preterm) & 78 & 1.02 & 29.67 & $22.90-38.44$ \\
\hline & 32-36 (moderately preterm) & 150 & 0.33 & 9.57 & $7.77-11.79$ \\
\hline & $37-41$ (term) & 215 & 0.03 & Referent & \\
\hline \multirow{3}{*}{$\begin{array}{l}\text { Spina Bifida } \\
\quad(741.000-741.999)\end{array}$} & 24-31 (very preterm) & 69 & 0.91 & 3.16 & $2.48-4.02$ \\
\hline & 32-36 (moderately preterm) & 363 & 0.80 & 2.79 & $2.49-3.12$ \\
\hline & $37-41($ term $)$ & 1,787 & 0.29 & Referent & \\
\hline \multirow{3}{*}{$\begin{array}{l}\text { Encephalocele } \\
\quad(742.000-742.099)\end{array}$} & 24-31 (very preterm) & 39 & 0.51 & 8.81 & $6.33-12.26$ \\
\hline & 32-36 (moderately preterm) & 103 & 0.23 & 3.90 & $3.14-4.86$ \\
\hline & $37-41$ (term) & 362 & 0.06 & Referent & \\
\hline \multirow{3}{*}{$\begin{array}{l}\text { Microcephalus } \\
\quad(742.100-742.199)\end{array}$} & 24-31 (very preterm) & 323 & 4.24 & 10.09 & $8.99-11.33$ \\
\hline & 32-36 (moderately preterm) & 925 & 2.04 & 4.85 & $4.50-5.22$ \\
\hline & $37-41$ (term) & 2,618 & 0.42 & Referent & \\
\hline \multirow{3}{*}{$\begin{array}{l}\text { Reduction deformities of } \\
\text { brain }(742.200-742.299)\end{array}$} & 24-31 (very preterm) & 202 & 2.65 & 10.28 & $8.88-11.9$ \\
\hline & 32-36 (moderately preterm) & 499 & 1.10 & 4.26 & $3.85-4.71$ \\
\hline & $37-41$ (term) & 1,607 & 0.26 & Referent & \\
\hline \multirow{3}{*}{$\begin{array}{l}\text { Congenital hydrocephalus } \\
(742.300-742.399)\end{array}$} & 24-31 (very preterm) & 1,012 & 13.29 & 31.24 & $29.06-33.59$ \\
\hline & 32-36 (moderately preterm) & 1,051 & 2.32 & 5.44 & $5.07-5.85$ \\
\hline & $37-41$ (term) & 2,649 & 0.43 & Referent & \\
\hline \multirow{3}{*}{$\begin{array}{l}\text { Eye, face, neck, ear defects } \\
\quad(743.000-744.999)\end{array}$} & 24-31 (very preterm) & 908 & 11.92 & 5.20 & $4.86-5.56$ \\
\hline & 32-36 (moderately preterm) & 2,679 & 5.90 & 2.57 & $2.47-2.68$ \\
\hline & $37-41$ (term) & 14,276 & 2.29 & Referent & \\
\hline \multirow{3}{*}{$\begin{array}{l}\text { Anophthalmia/ } \\
\text { microphthalmia } \\
\text { (743.000-743.199) }\end{array}$} & 24-31 (very preterm) & 99 & 1.30 & 10.77 & $8.73-13.28$ \\
\hline & 32-36 (moderately preterm) & 223 & 0.49 & 4.07 & $3.50-4.72$ \\
\hline & $37-41$ (term) & 752 & 0.12 & Referent & \\
\hline \multirow{3}{*}{$\begin{array}{l}\text { Congenital cataract } \\
\text { and lens anomalies } \\
(743.300-743.399)\end{array}$} & 24-31 (very preterm) & 72 & 0.95 & 6.41 & $5.04-8.14$ \\
\hline & 32-36 (moderately preterm) & 139 & 0.31 & 2.08 & $1.74-2.48$ \\
\hline & $37-41$ (term) & 919 & 0.15 & Referent & \\
\hline \multirow{3}{*}{$\begin{array}{l}\text { Congenital anomalies of } \\
\text { posterior segment } \\
(743.500-743.599)\end{array}$} & 24-31 (very preterm) & 102 & 1.34 & 17.45 & $14.09-21.61$ \\
\hline & 32-36 (moderately preterm) & 141 & 0.31 & 4.05 & $3.35-4.88$ \\
\hline & $37-41$ (term) & 478 & 0.08 & Referent & \\
\hline \multirow{3}{*}{$\begin{array}{l}\text { Congenital anomalies of } \\
\text { eyelids, lacrimal system, } \\
\text { and orbit } \\
(743.600-743.699)\end{array}$} & 24-31 (very preterm) & 135 & 1.77 & 3.41 & $2.87-4.05$ \\
\hline & 32-36 (moderately preterm) & 442 & 0.97 & 1.87 & $1.69-2.07$ \\
\hline & $37-41$ (term) & 3,240 & 0.52 & Referent & \\
\hline \multirow{3}{*}{$\begin{array}{l}\text { Anomalies of ear causing } \\
\text { impairment of hearing } \\
\text { (744.000-744.099) }\end{array}$} & 24-31 (very preterm) & 37 & 0.49 & 5.12 & $3.67-7.14$ \\
\hline & 32-36 (moderately preterm) & 134 & 0.30 & 3.11 & $2.58-3.75$ \\
\hline & $37-41($ term $)$ & 591 & 0.09 & Referent & \\
\hline \multirow{3}{*}{$\begin{array}{l}\text { Accessory auricle } \\
\quad(744.100-744.199)\end{array}$} & 24-31 (very preterm) & 38 & 0.50 & 2.24 & $1.62-3.09$ \\
\hline & 32-36 (moderately preterm) & 180 & 0.40 & 1.78 & $1.53-2.08$ \\
\hline & $37-41$ (term) & 1,386 & 0.22 & Referent & \\
\hline \multirow{3}{*}{$\begin{array}{l}\text { Cardiovascular defects } \\
\quad(745.000-747.999)\end{array}$} & 24-31 (very preterm) & 5,235 & 68.75 & 9.29 & $9.03-9.56$ \\
\hline & 32-36 (moderately preterm) & 10,574 & 23.30 & 3.15 & $3.08-3.21$ \\
\hline & $37-41$ (term) & 46,089 & 7.40 & Referent & \\
\hline
\end{tabular}


Table 4 continued

\begin{tabular}{|c|c|c|c|c|c|}
\hline $\begin{array}{l}\text { Defect category and } \\
\text { ICD codes }^{\mathrm{c}}\end{array}$ & $\begin{array}{l}\text { Gestational } \\
\text { age (weeks) }\end{array}$ & $\begin{array}{l}\text { Number of infants } \\
\text { with birth defects }\end{array}$ & $\begin{array}{l}\text { Prevalence (per } \\
1,000 \text { live births) }\end{array}$ & $\begin{array}{l}\text { Unadjusted } \\
\text { prevalence ratio }^{\mathrm{d}}\end{array}$ & $\begin{array}{l}95 \% \\
\mathrm{CI}^{\mathrm{d}}\end{array}$ \\
\hline \multirow{3}{*}{$\begin{array}{l}\text { Truncus arteriosus } \\
\qquad(745.000-745.019)\end{array}$} & 24-31 (very preterm) & 26 & 0.34 & 5.34 & $3.59-7.94$ \\
\hline & 32-36 (moderately preterm) & 93 & 0.20 & 3.21 & $2.56-4.02$ \\
\hline & $37-41$ (term) & 398 & 0.06 & Referent & \\
\hline \multirow{3}{*}{$\begin{array}{l}\text { Transposition of great } \\
\text { vessels } \\
\text { (745.100-745.199) }\end{array}$} & 24-31 (very preterm) & 61 & 0.80 & 2.20 & $1.71-2.84$ \\
\hline & 32-36 (moderately preterm) & 335 & 0.74 & 2.03 & $1.81-2.27$ \\
\hline & $37-41($ term $)$ & 2,268 & 0.36 & Referent & \\
\hline \multirow{3}{*}{$\begin{array}{l}\text { Tetralogy of Fallot } \\
\quad(745.200-745.299)\end{array}$} & 24-31 (very preterm) & 101 & 1.33 & 4.15 & $3.40-5.07$ \\
\hline & 32-36 (moderately preterm) & 433 & 0.95 & 2.99 & $2.69-3.31$ \\
\hline & $37-41($ term $)$ & 1,990 & 0.32 & Referent & \\
\hline \multirow{3}{*}{$\begin{array}{l}\text { Ventricular septal defect } \\
\quad(745.300-745.499)\end{array}$} & 24-31 (very preterm) & 1,191 & 15.64 & 5.09 & $4.80-5.39$ \\
\hline & 32-36 (moderately preterm) & 3,627 & 7.99 & 2.60 & $2.51-2.69$ \\
\hline & $37-41$ (term) & 19,143 & 3.07 & Referent & \\
\hline \multirow{3}{*}{$\begin{array}{l}\text { Endocardial cushion defects } \\
\quad(745.600-745.699)\end{array}$} & 24-31 (very preterm) & 71 & 0.93 & 3.29 & $2.60-4.17$ \\
\hline & 32-36 (moderately preterm) & 396 & 0.87 & 3.08 & $2.76-3.43$ \\
\hline & $37-41$ (term) & 1,764 & 0.28 & Referent & \\
\hline \multirow{3}{*}{$\begin{array}{l}\text { Anomalies of pulmonary } \\
\text { valve (746.000-746.099) }\end{array}$} & 24-31 (very preterm) & 821 & 10.78 & 15.30 & $14.20-16.48$ \\
\hline & 32-36 (moderately preterm) & 1,186 & 2.61 & 3.71 & $3.48-3.95$ \\
\hline & $37-41$ (term) & 4,388 & 0.70 & Referent & \\
\hline \multirow{3}{*}{$\begin{array}{l}\text { Tricuspid atresia and } \\
\text { stenosis } \\
(746.100-746.199)\end{array}$} & 24-31 (very preterm) & 784 & 10.30 & 11.80 & $10.95-12.72$ \\
\hline & 32-36 (moderately preterm) & 1,358 & 2.99 & 3.43 & $3.23-3.64$ \\
\hline & $37-41$ (term) & 5,432 & 0.87 & Referent & \\
\hline \multirow{3}{*}{$\begin{array}{l}\text { Congenital stenosis of } \\
\text { aortic valve } \\
(746.300-746.399)\end{array}$} & 24-31 (very preterm) & 39 & 0.51 & 3.01 & $2.19-4.15$ \\
\hline & 32-36 (moderately preterm) & 186 & 0.41 & 2.41 & $2.06-2.82$ \\
\hline & $37-41$ (term) & 1,058 & 0.17 & Referent & \\
\hline \multirow{3}{*}{$\begin{array}{l}\text { Congenital insufficiency of } \\
\text { aortic valve } \\
(746.400-746.499)\end{array}$} & 24-31 (very preterm) & 131 & 1.72 & 5.45 & $4.57-6.51$ \\
\hline & 32-36 (moderately preterm) & 427 & 0.94 & 2.98 & $2.69-3.31$ \\
\hline & $37-41$ (term) & 1,964 & 0.32 & Referent & \\
\hline \multirow{3}{*}{$\begin{array}{l}\text { Hypoplastic left heart } \\
\quad(746.500-746.599) \& \\
(746.700-746.799)\end{array}$} & 24-31 (very preterm) & 44 & 0.58 & 2.44 & $1.81-3.29$ \\
\hline & 32-36 (moderately preterm) & 228 & 0.50 & 2.12 & $1.84-2.43$ \\
\hline & 37-41 (term) & 1,477 & 0.24 & Referent & \\
\hline \multirow{3}{*}{$\begin{array}{l}\text { Coarctation of aorta } \\
\quad(747.100-747.199)\end{array}$} & 24-31 (very preterm) & 97 & 1.27 & 3.04 & $2.48-3.72$ \\
\hline & 32-36 (moderately preterm) & 384 & 0.85 & 2.02 & $1.81-2.25$ \\
\hline & $37-41($ term $)$ & 2,609 & 0.42 & Referent & \\
\hline \multirow{3}{*}{$\begin{array}{l}\text { Anomalies of pulmonary } \\
\text { artery }(747.300-747.399)\end{array}$} & 24-31 (very preterm) & 1,445 & 18.98 & 21.64 & $20.42-22.93$ \\
\hline & 32-36 (moderately preterm) & 1,849 & 4.07 & 4.65 & $4.41-4.90$ \\
\hline & $37-41($ term $)$ & 5,460 & 0.88 & Referent & \\
\hline \multirow{3}{*}{$\begin{array}{l}\text { Respiratory tract defects } \\
\quad(748.000-748.999)\end{array}$} & 24-31 (very preterm) & 1,116 & 14.66 & 11.51 & $10.81-12.25$ \\
\hline & 32-36 (moderately preterm) & 1,675 & 3.69 & 2.90 & $2.75-3.05$ \\
\hline & $37-41$ (term) & 7,931 & 1.27 & Referent & \\
\hline \multirow{3}{*}{$\begin{array}{l}\text { Choanal atresia } \\
\qquad(748.000-748.099)\end{array}$} & 24-31 (very preterm) & 40 & 0.53 & 4.15 & $3.02-5.70$ \\
\hline & 32-36 (moderately preterm) & 162 & 0.36 & 2.82 & $2.38-3.34$ \\
\hline & 37-41 (term) & 788 & 0.13 & Referent & \\
\hline \multirow{3}{*}{$\begin{array}{l}\text { Orofacial defects } \\
\qquad(749.000-749.299)\end{array}$} & 24-31 (very preterm) & 277 & 3.64 & 2.78 & $2.47-3.13$ \\
\hline & 32-36 (moderately preterm) & 1,109 & 2.44 & 1.87 & $1.75-1.99$ \\
\hline & $37-41($ term $)$ & 8,150 & 1.31 & Referent & \\
\hline \multirow{3}{*}{$\begin{array}{l}\text { Cleft palate alone } \\
\quad(749.000-749.099)\end{array}$} & 24-31 (very preterm) & 133 & 1.75 & 3.20 & $2.69-3.81$ \\
\hline & 32-36 (moderately preterm) & 507 & 1.12 & 2.05 & $1.87-2.25$ \\
\hline & $37-41$ (term) & 3,396 & 0.55 & Referent & \\
\hline
\end{tabular}


Table 4 continued

\begin{tabular}{|c|c|c|c|c|c|}
\hline $\begin{array}{l}\text { Defect category and } \\
\text { ICD codes }^{\text {c }}\end{array}$ & $\begin{array}{l}\text { Gestational } \\
\text { age (weeks) }\end{array}$ & $\begin{array}{l}\text { Number of infants } \\
\text { with birth defects }\end{array}$ & $\begin{array}{l}\text { Prevalence (per } \\
1,000 \text { live births) }\end{array}$ & $\begin{array}{l}\text { Unadjusted } \\
\text { prevalence ratio }^{d}\end{array}$ & $\begin{array}{l}95 \% \\
\mathrm{CI}^{\mathrm{d}}\end{array}$ \\
\hline \multirow{3}{*}{$\begin{array}{l}\text { Cleft lip with or without } \\
\text { cleft palate } \\
(749.100-749.299)\end{array}$} & 24-31 (very preterm) & 148 & 1.94 & 2.39 & $2.03-2.81$ \\
\hline & 32-36 (moderately preterm) & 633 & 1.39 & 1.71 & $1.58-1.86$ \\
\hline & $37-41$ (term) & 5,073 & 0.81 & Referent & \\
\hline \multirow{3}{*}{$\begin{array}{l}\text { Gastrointestinal defects } \\
(750.000-751.999)\end{array}$} & 24-31 (very preterm) & 1,316 & 17.28 & 4.98 & $4.71-5.27$ \\
\hline & 32-36 (moderately preterm) & 4,426 & 9.75 & 2.81 & $2.72-2.90$ \\
\hline & $37-41$ (term) & 21,596 & 3.47 & Referent & \\
\hline \multirow{3}{*}{$\begin{array}{l}\text { Tracheoesophageal (T E) } \\
\text { fistula, esophageal atresia } \\
\text { and stenosis } \\
(750.300-750.399)\end{array}$} & 24-31 (very preterm) & 153 & 2.01 & 11.66 & $9.84-13.81$ \\
\hline & 32-36 (moderately preterm) & 470 & 1.04 & 6.01 & $5.39-6.70$ \\
\hline & $37-41$ (term) & 1,073 & 0.17 & Referent & \\
\hline \multirow{3}{*}{$\begin{array}{l}\text { Congenital hypertrophic } \\
\text { pyloric stenosis } \\
(750.500-750.599)\end{array}$} & 24-31 (very preterm) & 148 & 1.94 & 1.26 & $1.07-1.48$ \\
\hline & 32-36 (moderately preterm) & 990 & 2.18 & 1.42 & $1.33-1.51$ \\
\hline & $37-41$ (term) & 9,587 & 1.54 & Referent & \\
\hline \multirow{3}{*}{$\begin{array}{l}\text { Atresia and stenosis of } \\
\text { small intestine } \\
(751.100-751.199)\end{array}$} & 24-31 (very preterm) & 214 & 2.81 & 12.39 & $10.73-14.30$ \\
\hline & 32-36 (moderately preterm) & 861 & 1.90 & 8.36 & $7.68-9.10$ \\
\hline & $37-41$ (term) & 1,413 & 0.23 & Referent & \\
\hline \multirow{3}{*}{$\begin{array}{l}\text { Atresia and stenosis of large } \\
\text { intestine, rectum and anal } \\
\text { canal (751.200-751.299) }\end{array}$} & 24-31 (very preterm) & 183 & 2.40 & 7.21 & $6.19-8.38$ \\
\hline & 32-36 (moderately preterm) & 553 & 1.22 & 3.65 & $3.33-4.01$ \\
\hline & $37-41$ (term) & 2,077 & 0.33 & Referent & \\
\hline \multirow{3}{*}{$\begin{array}{l}\text { Hirschsprung disease and } \\
\text { other congenital } \\
\text { functional disorders of } \\
\text { the colon } \\
(751.300-751.399)\end{array}$} & 24-31 (very preterm) & 56 & 0.74 & 3.85 & $2.94-5.03$ \\
\hline & 32-36 (moderately preterm) & 183 & 0.40 & 2.11 & $1.81-2.47$ \\
\hline & $37-41$ (term) & 1,190 & 0.19 & Referent & \\
\hline \multirow{3}{*}{$\begin{array}{c}\text { Genitourinary defects } \\
(752.000-753.999)\end{array}$} & 24-31 (very preterm) & 2,060 & 27.05 & 4.09 & $3.91-4.27$ \\
\hline & 32-36 (moderately preterm) & 6,783 & 14.95 & 2.26 & $2.20-2.32$ \\
\hline & $37-41$ (term) & 41,213 & 6.62 & Referent & \\
\hline \multirow{3}{*}{$\begin{array}{l}\text { Anomalies of cervix, } \\
\text { vagina, and external } \\
\text { female genitalia } \\
(752.400-752.499)\end{array}$} & 24-31 (very preterm) & 103 & 1.35 & 4.46 & $3.66-5.44$ \\
\hline & 32-36 (moderately preterm) & 332 & 0.73 & 2.41 & $2.15-2.71$ \\
\hline & $37-41($ term $)$ & 1,888 & 0.30 & Referent & \\
\hline \multirow{3}{*}{$\begin{array}{l}\text { Hypospadias } \\
\quad(752.600-752.699)\end{array}$} & 24-31 (very preterm) & 827 & 10.86 & 3.31 & $3.09-3.55$ \\
\hline & 32-36 (moderately preterm) & 2,684 & 5.91 & 1.80 & $1.73-1.88$ \\
\hline & 37-41 (term) & 20,445 & 3.28 & Referent & \\
\hline \multirow{3}{*}{$\begin{array}{l}\text { Renal agenesis and } \\
\text { dysgenesis } \\
(753.000-753.099)\end{array}$} & 24-31 (very preterm) & 207 & 2.72 & 10.08 & $8.72-11.64$ \\
\hline & 32-36 (moderately preterm) & 628 & 1.38 & 5.13 & $4.68-5.62$ \\
\hline & $37-41$ (term) & 1,680 & 0.27 & Referent & \\
\hline \multirow{3}{*}{$\begin{array}{l}\text { Musculoskeletal defects } \\
\quad(754.000-756.999)\end{array}$} & 24-31 (very preterm) & 2,317 & 30.43 & 3.41 & $3.27-3.56$ \\
\hline & 32-36 (moderately preterm) & 8,722 & 19.22 & 2.15 & $2.11-2.20$ \\
\hline & $37-41$ (term) & 55,540 & 8.92 & Referent & \\
\hline \multirow{3}{*}{$\begin{array}{l}\text { Congenital dislocation of } \\
\text { hip (754.300-754.399) }\end{array}$} & 24-31 (very preterm) & 169 & 2.22 & 1.48 & $1.27-1.72$ \\
\hline & 32-36 (moderately preterm) & 794 & 1.75 & 1.17 & $1.09-1.25$ \\
\hline & $37-41$ (term) & 9,337 & 1.50 & Referent & \\
\hline \multirow[t]{3}{*}{ Clubfeet (754.500-754.799) } & 24-31 (very preterm) & 452 & 5.94 & 3.12 & $2.84-3.43$ \\
\hline & 32-36 (moderately preterm) & 1,770 & 3.90 & 2.05 & $1.95-2.15$ \\
\hline & $37-41$ (term) & 11,853 & 1.90 & Referent & \\
\hline \multirow{3}{*}{$\begin{array}{l}\text { Limb reduction defects } \\
\quad(755.200-755.499)\end{array}$} & 24-31 (very preterm) & 102 & 1.34 & 4.33 & $3.55-5.29$ \\
\hline & 32-36 (moderately preterm) & 423 & 0.93 & 3.01 & $2.71-3.35$ \\
\hline & 37-41 (term) & 1,925 & 0.31 & Referent & \\
\hline
\end{tabular}


Table 4 continued

\begin{tabular}{|c|c|c|c|c|c|}
\hline $\begin{array}{l}\text { Defect category and } \\
\text { ICD codes }^{\mathrm{c}}\end{array}$ & $\begin{array}{l}\text { Gestational } \\
\text { age (weeks) }\end{array}$ & $\begin{array}{l}\text { Number of infants } \\
\text { with birth defects }\end{array}$ & $\begin{array}{l}\text { Prevalence (per } \\
1,000 \text { live births) }\end{array}$ & $\begin{array}{l}\text { Unadjusted } \\
\text { prevalence ratio }^{\mathrm{d}}\end{array}$ & $\begin{array}{l}95 \% \\
\mathrm{CI}^{\mathrm{d}}\end{array}$ \\
\hline \multirow{3}{*}{$\begin{array}{l}\text { Anomalies of abdominal } \\
\text { wall (756.700-756.799) }\end{array}$} & 24-31 (very preterm) & 164 & 2.15 & 7.71 & $6.57-9.05$ \\
\hline & 32-36 (moderately preterm) & 1,172 & 2.58 & 9.24 & $8.58-9.95$ \\
\hline & $37-41($ term $)$ & 1,740 & 0.28 & Referent & \\
\hline \multirow{3}{*}{$\begin{array}{l}\text { Skin defects } \\
\qquad(757.000-757.999)\end{array}$} & 24-31 (very preterm) & 262 & 3.44 & 2.12 & $1.87-2.39$ \\
\hline & 32-36 (moderately preterm) & 1,504 & 3.31 & 2.04 & $1.93-2.15$ \\
\hline & $37-41($ term $)$ & 10,119 & 1.63 & Referent & \\
\hline \multirow{3}{*}{$\begin{array}{l}\text { Chromosomal defects } \\
\quad(758.000-758.999)\end{array}$} & 24-31 (very preterm) & 480 & 6.30 & 4.40 & $4.02-4.83$ \\
\hline & 32-36 (moderately preterm) & 2,406 & 5.30 & 3.70 & $3.54-3.87$ \\
\hline & $37-41($ term $)$ & 8,913 & 1.43 & Referent & \\
\hline \multirow{3}{*}{$\begin{array}{l}\text { Down syndrome (trisomy } \\
21)(758.000-758.099)\end{array}$} & 24-31 (very preterm) & 173 & 2.27 & 2.52 & $2.17-2.93$ \\
\hline & 32-36 (moderately preterm) & 1,386 & 3.05 & 3.39 & $3.19-3.59$ \\
\hline & $37-41$ (term) & 5,616 & 0.90 & Referent & \\
\hline \multirow{3}{*}{$\begin{array}{l}\text { Trisomy } 13 \\
\quad(758.100-758.199)\end{array}$} & 24-31 (very preterm) & 56 & 0.74 & 13.05 & $9.84-17.30$ \\
\hline & 32-36 (moderately preterm) & 168 & 0.37 & 6.57 & $5.46-7.89$ \\
\hline & $37-41$ (term) & 351 & 0.06 & Referent & \\
\hline \multirow{3}{*}{$\begin{array}{l}\text { Trisomy } 18 \\
\quad(758.200-758.299)\end{array}$} & 24-31 (very preterm) & 98 & 1.29 & 15.59 & $12.56-19.35$ \\
\hline & 32-36 (moderately preterm) & 231 & 0.51 & 6.17 & $5.28-7.20$ \\
\hline & 37-41 (term) & 514 & 0.08 & Referent & \\
\hline
\end{tabular}

${ }^{a}$ Combined data from: Colorado, Georgia, Hawaii, Illinois, Kentucky, Michigan, Missouri, New York, North Carolina, Oklahoma, Rhode Island, Texas, and West Virginia

b All states included data for 1995-2000 except Kentucky and Rhode Island (1998-2000) and Texas (1996-2000)

${ }^{c}$ Defects are coded using the British Paediatric Association codes, which are based on the International Classification of Diseases (ICD) Clinical Modification. Infants with more than one major defect are counted in each category in which they have a defect. Infants with defect codes in ICD-9-CM code 759 are not included in this table, but are included in Tables 1-3

${ }^{d}$ Prevalence ratio and 95\% Confidence Interval calculated using SAS PROC GENMOD

prior to 24 weeks gestation [42, 44, 45]. Case ascertainment methodologies differ between birth defects surveillance systems, from major differences (passive vs. active ascertainment) to minor differences such as sources utilized. Some birth defects surveillance programs used prematurity as a criterion for reviewing newborn records, which could have led to disproportionately better ascertainment of birth defects among preterm infants compared with term infants, potentially resulting in inflated prevalence ratios for preterm birth. Also, we were not able to remove all prematurity- related defects because some of the programs did not code the cases to a sufficient level of detail to verify certain exclusions. For example, hydrocephalus secondary to intraventricular hemorrhage should be excluded from this analysis; however, we were not able to verify the extent to which each participating surveillance system appropriately excluded hydrocephalus cases of this type. In addition, data were missing for some variables, which could have led to bias if missing information was not random, but was instead more likely to be missing among high-risk populations, and data were not available on some potential confounders of interest such as first trimester maternal smoking. Finally, residents who delivered infants with birth defects out of state and did not subsequently receive treatment within the state might not be captured by the birth defects surveillance system, because many systems do not have interstate data exchange agreements [46].

\section{Conclusions}

There is a strong relation between birth defects and preterm birth in the United States, with the strongest association between preterm births and birth defects observed at the earliest gestational ages. Further research is needed to identify common pathways and shared risk factors to help prevent these two major contributors to infant morbidity and mortality in the United States, and to understand the factors that lead to preterm birth among those infants affected by major birth defects.

Acknowledgements We thank the State Data Committee of the National Birth Defects Prevention Network and staff from the following state programs for their contributions of data: CDCMetropolitan Atlanta Congenital Defects Program (CDC-MACDP), Colorado Responds to Children with Special Needs (CRCSN), Hawaii Birth Defects Program (HBDP), Illinois Adverse Pregnancy 
Outcomes Reporting System (APORS), Kentucky Birth Surveillance Registry, Michigan Birth Defects Registry (MBDR), Missouri Birth Defects Registry, New York State Congenital Malformations Registry (CMR), North Carolina Birth Defects Monitoring Program (NCBDMP), Oklahoma Birth Defects Registry (OBDR), Rhode Island Birth Defects Program, Texas Birth Defects Registry, and West Virginia Congenital Abnormalities Registry, Education and Surveillance System (WVCARES). We also thank Larry Edmonds and Owen Devine for their assistance and guidance and March of Dimes Foundation for their support of two analysts (J. Xing and N. Yuskiv) working on this project. This work was supported in part by the March of Dimes Foundation and the Centers for Disease Control and Prevention. The findings and conclusions in this report are those of the authors and do not necessarily represent the views of the Centers for Disease Control and Prevention.

\section{References}

1. Petrini, J., Damus, K., Russell, R., Poschman, K., Davidoff, M. J., \& Mattison, D. (2002). Contribution of birth defects to infant mortality in the United States. Teratology, 66(Suppl 1), S3-S6. doi:10.1002/tera.90002.

2. Rasmussen, S. A., Moore, C. A., Paulozzi, L. J., \& Rhodenhiser, E. P. (2001). Risk for birth defects among premature infants: A population-based study. The Journal of Pediatrics, 138(5), 668673. doi:10.1067/mpd.2001.112249.

3. Hoyert, D. L., Mathews, T. J., Menacker, F., Strobino, D. M., \& Guyer, B. (2006). Annual summary of vital statistics: 2004. Pediatrics, 117(1), 168-183. doi:10.1542/peds.2005-2587.

4. Institute of Medicine. (2006). Preterm birth: Causes, consequences, and prevention. Washington, DC: National Academies Press.

5. Grandi, C., Luchtenberg, G., \& Rittler, M. (2007). The contribution of birth defects to spontaneous preterm birth. American Journal of Perinatology, 24(8), 487-492. doi:10.1055/s-2007986682.

6. Mili, F., Edmonds, L. D., Khoury, M. J., \& McClearn, A. B. (1991). Prevalence of birth defects among low-birth-weight infants. A population study. American Journal of Diseases of Children, 145(11), 1313-1318.

7. Shaw, G. M., Savitz, D. A., Nelson, V., \& Thorp, J. M. Jr. (2001). Role of structural birth defects in preterm delivery. Paediatric and Perinatal Epidemiology, 15(2), 106-109. doi:10.1046/ j.1365-3016.2001.00334.x.

8. National Birth Defects Prevention Network (NBDPN). (2005). 2005 congenital malformations surveillance report. Birth Defects Research. Part A, Clinical and Molecular Teratology, 73(10), 758-853. doi:10.1002/bdra.20214.

9. Martin, J. A., Hamilton, B. E., Ventura, S. J., Menacker, F., \& Park, M. M. (2002). Births: Final data for 2000. National Vital Statistics Reports, 50(5), 1-101.

10. Alexander, G. R., Himes, J. H., Kaufman, R. B., Mor, J., \& Kogan, M. (1996). A United States national reference for fetal growth. Obstetrics and Gynecology, 87(2), 163-168. doi: 10.1016/0029-7844(95)00386-X.

11. Rothman, K. J., \& Greenland, S. (1998). Modern epidemiology (2nd ed.). Philadelphia: Lippincott-Raven Publishers.

12. Centers for Disease Control and Prevention (CDC), National Center for Health Statistics (NCHS), Division of Vital Statistics, Natality public-use data on CDC WONDER On-line Database, 1995-2002, published November 2005. Accessed at: http://wonder. cdc.gov/wonder/help/Natality.html\#.

13. Kyrklund-Blomberg, N. B., Granath, F., \& Cnattingius, S. (2005). Maternal smoking and causes of very preterm birth. Acta
Obstetricia et Gynecologica Scandinavica, 84(6), 572-577. doi: 10.1111/j.0001-6349.2005.00848.x.

14. Rosenberg, T. J., Garbers, S., Lipkind, H., \& Chiasson, M. A. (2005). Maternal obesity and diabetes as risk factors for adverse pregnancy outcomes: Differences among 4 racial/ethnic groups. American Journal of Public Health, 95(9), 1545-1551. doi: 10.2105/AJPH.2005.065680.

15. Lynberg, M., \& Edmonds, L. (1992). Surveillance of birth defects. In E. W. Halperin \& E. L. Baker Jr. (Eds.), Public health surveillance (pp. 157-172). New York: Van Nostrand Reinhold.

16. Dolan, S. M., Gross, S. J., Merkatz, I. R., et al. (2007). The contribution of birth defects to preterm birth and low birth weight. Obstetrics and Gynecology, 110(2 Pt 1), 318-324.

17. Tanner, K., Sabrine, N., \& Wren, C. (2005). Cardiovascular malformations among preterm infants. Pediatrics, 116(6), e833e838. doi:10.1542/peds.2005-0397.

18. Resnik, R. (2002). Intrauterine growth restriction. Obstetrics and Gynecology, 99(3), 490-496. doi:10.1016/S0029-7844(01) 01780-X.

19. Group, M. V. S. R. (1991). Prevention of neural tube defects: Results of the medical research council vitamin study. MRC vitamin study research group. Lancet, 338(8760), 131-137. doi: 10.1016/0140-6736(91)90133-A.

20. Czeizel, A. E., \& Dudas, I. (1992). Prevention of the first occurrence of neural-tube defects by periconceptional vitamin supplementation. The New England Journal of Medicine, 327(26), 1832-1835.

21. Berry, R. J., Li, Z., Erickson, J. D., et al. (1999). Prevention of neural-tube defects with folic acid in China. China-U.S. collaborative project for neural tube defect prevention. The New England Journal of Medicine, 341(20), 1485-1490. doi: 10.1056/NEJM199911113412001.

22. Honein, M. A., Paulozzi, L. J., Mathews, T. J., Erickson, J. D., \& Wong, L. Y. (2001). Impact of folic acid fortification of the US food supply on the occurrence of neural tube defects. Journal of the American Medical Association, 285(23), 2981-2986. doi: 10.1001/jama.285.23.2981.

23. Williams, L. J., Mai, C. T., Edmonds, L. D., et al. (2002). Prevalence of spina bifida and anencephaly during the transition to mandatory folic acid fortification in the United States. Teratology, 66(1), 33-39. doi:10.1002/tera.10060.

24. Botto, L. D., Olney, R. S., \& Erickson, J. D. (2004). Vitamin supplements and the risk for congenital anomalies other than neural tube defects. American Journal of Medical Genetics. Part C, Seminars in Medical Genetics, 125(1), 12-21. doi: 10.1002/ajmg.c.30004.

25. Canfield, M. A., Collins, J. S., Botto, L. D. et al. (2005). Changes in the birth prevalence of selected birth defects after grain fortification with folic acid in the United States: Findings from a multi-state population-based study. Birth defects Research. Part A, Clinical and Molecular Teratology, 73(10), 679-689. doi: 10.1002/bdra.20210.

26. Relton, C. L., Pearce, M. S., \& Parker, L. (2005). The influence of erythrocyte folate and serum vitamin B12 status on birth weight. The British Journal of Nutrition, 93(5), 593-599. doi: 10.1079/BJN20041395.

27. Siega-Riz, A. M., Savitz, D. A., Zeisel, S. H., Thorp, J. M., \& Herring, A. (2004). Second trimester folate status and preterm birth. American Journal of Obstetrics and Gynecology, 191(6), 1851-1857. doi:10.1016/j.ajog.2004.07.076.

28. Honein, M. A., Paulozzi, L. J., \& Watkins, M. L. (2001). Maternal smoking and birth defects: validity of birth certificate data for effect estimation. Public Health Reports, 116(4), 327-335.

29. Shah, N. R., \& Bracken, M. B. (2000). A systematic review and meta-analysis of prospective studies on the association between maternal cigarette smoking and preterm delivery. American 
Journal of Obstetrics and Gynecology, 182(2), 465-472. doi: 10.1016/S0002-9378(00)70240-7.

30. Waller, D. K., Mills, J. L., Simpson, J. L., et al. (1994). Are obese women at higher risk for producing malformed offspring? American Journal of Obstetrics and Gynecology, 170(2), 541-548.

31. Watkins, M. L., Rasmussen, S. A., Honein, M. A., Botto, L. D., \& Moore, C. A. (2003). Maternal obesity and risk for birth defects. Pediatrics, 111(5 Part 2), 1152-1158.

32. Anderson, J. L., Waller, D. K., Canfield, M. A., Shaw, G. M., Watkins, M. L., \& Werler, M. M. (2005). Maternal obesity, gestational diabetes, and central nervous system birth defects. Epidemiology, 16(1), 87-92. doi:10.1097/01.ede.0000147122. 97061.bb.

33. Castro, L. C., \& Avina, R. L. (2002). Maternal obesity and pregnancy outcomes. Current Opinion in Obstetrics \& Gynecology, 14(6), 601-606. doi:10.1097/00001703-20021200000005.

34. Davidoff, M. J., Petrini, J., Damus, K., Russell, R. B., \& Mattison, D. (2002). Neural tube defect-specific infant mortality in the United States. Teratology, 66(Suppl 1), S17-S22. doi: 10.1002/tera.90005.

35. Cannon, C., Dildy, G. A., Ward, R., Varner, M. W., \& Dudley, D. J. (1996). A population-based study of congenital diaphragmatic hernia in Utah: 1988-1994. Obstetrics and Gynecology, 87(6), 959-963. doi:10.1016/0029-7844(96)00052-X.

36. Dees, E., Lin, H., Cotton, R. B., Graham, T. P., \& Dodd, D. A. (2000). Outcome of preterm infants with congenital heart disease. The Journal of Pediatrics, 137(5), 653-659. doi: 10.1067/mpd.2000.108568.

37. McMahon, C. J., Penny, D. J., Nelson, D. P., et al. (2005). Preterm infants with congenital heart disease and bronchopulmonary dysplasia: postoperative course and outcome after cardiac surgery. Pediatrics, 116(2), 423-430. doi:10.1542/peds.2004-2168.

38. Moir, C. R., Ramsey, P. S., Ogburn, P. L., Johnson, R. V., \& Ramin, K. D. (2004). A prospective trial of elective preterm delivery for fetal gastroschisis. American Journal of Perinatology, 21(5), 289-294. doi:10.1055/s-2004-829864.

39. Ergun, O., Barksdale, E., Ergun, F. S., et al. (2005). The timing of delivery of infants with gastroschisis influences outcome. Journal of Pediatric Surgery, 40(2), 424-428. doi:10.1016/j.jpedsurg. 2004.10.013.

40. Brantberg, A., Blaas, H. G., Salvesen, K. A., Haugen, S. E., \& Eik-Nes, S. H. (2004). Surveillance and outcome of fetuses with gastroschisis. Ultrasound Obstetrics and Gynecology, 23(1), 4-13. doi:10.1002/uog.950.

41. Alexander, G. R., \& Allen, M. C. (1996). Conceptualization, measurement, and use of gestational age. I. Clinical and public health practice. Journal of Perinatology, 16(1), 53-59.

42. Lumley, J. (2003). Defining the problem: the epidemiology of preterm birth. British Journal of Obstetrics and Gynaecology, 110(20), 3-7.

43. Goldenberg, R. L., Davis, R. O., Cutter, G. R., Hoffman, H. J., Brumfield, C. G., \& Foster, J. M. (1989). Prematurity, postdates, and growth retardation: The influence of use of ultrasonography on reported gestational age. American Journal of Obstetrics and Gynecology, 160(2), 462-470.

44. Liu, S., Joseph, K. S., Kramer, M. S., et al. (2002). Relationship of prenatal diagnosis and pregnancy termination to overall infant mortality in Canada. Journal of the American Medical Association, 287(12), 1561-1567. doi:10.1001/jama.287.12.1561.

45. Hassed, S. J., Miller, C. H., Pope, S. K., Murphy, P., Quirk, J. G., Jr., \& Cunniff, C. (1993). Perinatal lethal conditions: the effect of diagnosis on decision making. Obstetrics and Gynecology, 82(1), $37-42$.

46. Cassell, C., Mai, C., \& Rickard, R. (2007). Birth defects interstate data exchange: A battle worth fighting?. Birth Defects Research. Part A, Clinical and Molecular Teratology, 79(11), 806-810. doi: 10.1002/bdra.20413. 